\title{
Published and not fully published double-blind, randomised, controlled trials with oral naratriptan in the treatment of migraine: a review based on the GSK Trial Register
}

\author{
Peer Carsten Tfelt-Hansen
}

Received: 29 January 2011/ Accepted: 5 March 2011 / Published online: 25 March 2011

(C) The Author(s) 2011. This article is published with open access at Springerlink.com

\begin{abstract}
Naratriptan $2.5 \mathrm{mg}$ is now an over-the-counter drug in Germany. This should increase the interest in drug. The GSK Trial Register was searched for published and unpublished double-blind, randomised, controlled trials (RCTs) concerning the use of naratriptan in migraine. Only 7 of 17 RCTs are published in full. Naratriptan $2.5 \mathrm{mg}$ is superior to placebo for acute migraine treatment in $6 \mathrm{RCTs}$, but inferior to sumatriptan $100 \mathrm{mg}$ and rizatriptan $10 \mathrm{mg}$ in one RCT each. This dose of naratriptan has no more adverse events than placebo. Naratriptan $1 \mathrm{mg}$ b.i.d. has some effect in the short-term prophylactic treatment of menstruation-associated migraine in 3 RCTs. In 2 RCTs, naratriptan $2.5 \mathrm{mg}$ was equivalent to naproxen sodium $375 \mathrm{mg}$ for migraine-related quality of life. Naratriptan $2.5 \mathrm{mg}$ (34\% preference) was superior to naproxen sodium $500 \mathrm{mg}$ ( $25 \%$ preference). Naratriptan $2.5 \mathrm{mg}$ is better than placebo in the acute treatment of migraine. The adverse effect profile of naratriptan $2.5 \mathrm{mg}$ is similar to that of placebo. The efficacy of naratriptan $2.5 \mathrm{mg}$ versus NSAIDs is not sufficiently investigated. Naratriptan, when available OTC is a reasonable second or third choice on the step care ladder in the acute treatment of migraine.
\end{abstract}

Keywords Naratriptan · Unpublished clinical trials · Migraine

P. C. Tfelt-Hansen ( $\square)$

Department of Neurology, Danish Headache Center,

Glostrup Hospital, University of Copenhagen,

Glostrup, Denmark

e-mail: ptha@glo.regionh.dk

\section{Introduction}

In Germany, the 5-hydroxytryptamine $(5-\mathrm{HT})_{1 \mathrm{~B} / 1 \mathrm{D}}$ receptor agonist naratriptan is an over-the-counter (OTC) drug, most likely because of its excellent tolerability [1-3]. The time to maximum blood concentration is $2 \mathrm{~h}$ for oral naratriptan, and $1.5 \mathrm{~h}$ for oral sumatriptan [2, 4]. The oral bioavailability of naratriptan is $74 \%$, and much higher than the $14 \%$ availability of sumatriptan [4]. The elimination half-lives of naratriptan and sumatriptan are 5.5 and $2 \mathrm{~h}$, respectively [4]. Naratriptan $2.5 \mathrm{mg}$ tablets have a placebolike tolerability profile and are associated with a low incidence of headache recurrence [5]. Thus, the $2.5-\mathrm{mg}$ dose offers some advantages over other $5-\mathrm{HT}_{1 \mathrm{~B} / 1 \mathrm{D}}$ agonists, and naratriptan has been called the "gentle triptan" [5].

In 1998, the Ethics Subcommittee of the International Headache Society [6] stated that the "responsibility for publication cannot be separated from the ethical responsibility of the investigator". The Subcommittee agreed that "scientists have an ethical obligation to submit creditable research results for publication, and should not enter into agreements that interfere with their control over the decision to publish." As a general rule, every methodologically sound, randomised, controlled trial should be published to allow an evaluation of the results; publication solely as an abstract or in non-peer-reviewed supplements is unacceptable [6].

Recently, I reported on six unpublished randomised controlled trials (RCTs) with sumatriptan [7]. These RCTs were found in the GlaxoSmithKline (GSK) Trial Register, and I became aware of unpublished RCT with naratriptan. Because naratriptan is now becoming an OTC drug in some countries, a review of all RCTs is relevant. In the present review of 17 double-blind, randomised, controlled trials 
(RCTs) in the naratriptan part of the GSK Trial Register, it was remarkable that less than half of these RCTs were fully published in peer-reviewed journals.

\section{Methods}

The GSK Register (http://www.gsk-clinicalstudyregister. com/) for naratriptan, which consists of 47 phase I to phase IV clinical studies, was searched for double-blind RCTs with oral naratriptan for migraine treatment regardless of the dose of naratriptan. The following data were extracted from the summary reports of each double-blind RCT (see Table 1): (1) doses of naratriptan, doses of other drugs, and the use of placebo; (2) number of centers; (3) total number of patients; (4) full publication (yes/no); (5) publication as an abstract (yes/no); and (6) reported results (either from the summary or from the full publication).

\section{Results}

All RCTs were multicenter RCTs (Table 1). Twelve out of 17 RCTs [8-24] were placebo-controlled, and in 5 RCTs [10, 20-22, 24] there was a presumably active comparator.

The median number of participating centers per RCT was 51 (range 10-152). In these 17 RCTs, the median number of patients was 236 (range 168-1,141). Seven RCTs $[11,14,15,17,19,20,23]$ were fully published in a peer-reviewed journal. Ten RCTs [12-17, 19, 21, 23, 28] were published as an abstract, and 6 RCTs [8-10, 18, 22, 23] were never published.

Naratriptan 2.5-10 mg was superior to placebo for acute migraine treatment in all 6 RCTs in adults $[11,14,15,17$, $21,23]$, whereas naratriptan $2.5 \mathrm{mg}$ was not superior to placebo in adolescents [16]. In 3 RCTs [11-13], short-term prophylaxis with naratriptan $1 \mathrm{mg}$ b.i.d was superior to placebo for menstruation-associated migraine (MAM). In 2 RCTs [8, 9], naratriptan $2.5 \mathrm{mg}$ was equivalent to naproxen sodium $375 \mathrm{mg}$ for migraine-related quality of life. Naratriptan $2.5 \mathrm{mg}$ (34\% preference) was superior to naproxen sodium $500 \mathrm{mg}$ (25\% preference) [10]. Naratriptan $2.5 \mathrm{mg}$ [66\% headache relief (HR) at $4 \mathrm{~h}$ ] was inferior to sumatriptan $100 \mathrm{mg}(76 \% \mathrm{HR}$ at $4 \mathrm{~h})$ in one RCT [21], whereas the higher $10-\mathrm{mg}$ dose of naratriptan $(80 \% \mathrm{HR}$ at $4 \mathrm{~h}$ ) was quite similar to sumatriptan $100 \mathrm{mg}(80 \% \mathrm{HR}$ at $4 \mathrm{~h})$ [24].

\section{Discussion}

A recent review on reporting bias in clinical trials [25] concluded that "the prevalence of incomplete outcome reporting is high". In addition, when all randomised controlled trials (RCTs) are not published, it results in publication bias, which can be considerable and can distort available evidence [26].

Publication of well-conducted RCTs is primarily the responsibility of the clinical investigators. However, all the RCTs on naratriptan were multicenter trials (range 10-152 centers) and the pharmaceutical company, GSK was most likely fully in control of both the conduct and the publication of the RCTs. Seven pivotal RCTs [11, 14, 15, 17, 19, 21, 23] were fully published, but one was not [21] (see Table 1). The reasons for not publishing the 10 other RCT in full remains unknown.

Notably, the 2,729 patients included in the fully published RCTs represent less than half (45\%) of the 6,112 patients participating in the naratriptan trial program. When migraine patients were recruited to an RCT, which may include placebo or a less effective drug, for up to $4 \mathrm{~h}$, it should be an obligation to publish the results in a peer-reviewed journal. The conduct of RCTs solely for registration purposes, without full publication, should be avoided. The data presented in this review should be and are now in the public domain. They confirm, as expected, that naratriptan is superior to placebo as was also found in meta-analyses [1-3]. It should be noted, however, that headache relief (a decrease in headache from moderate or severe to none or mild) was first measured after $4 \mathrm{~h}$ because naratriptan is generally held to be a slow-acting triptan [5]. The "slow onset of action" (a delay in onset) of naratriptan was apparently confirmed in one RCT (see Fig. 1) [21]. After $2 \mathrm{~h}$, the headache relief for patients taking sumatriptan $100 \mathrm{mg}$ and for naratriptan $2.5 \mathrm{mg}$ were 59 and $50 \%$, respectively. After $2 \mathrm{~h}$, the curves for headache relief were parallel, with the endpoint headache relief at $4 \mathrm{~h}$ for sumatriptan $100 \mathrm{mg}$ at $76 \%$ and naratriptan $2.5 \mathrm{mg}$ at $66 \%$. Thus, it is difficult to judge the speed of onset of action of the two drugs when the final endpoints are different [27]. In contrast, in an RCT using the higher 10-mg dose of naratriptan versus $100 \mathrm{mg}$ sumatriptan, the endpoint of 4-h headache relief was similar, at $80 \%$, for both groups [24]. As shown in Fig. 2, there is no difference in the "onset of action" when equipotent doses of the two drugs are used. Thus, naratriptan is not a slow-acting drug per se.

Naratriptan $1 \mathrm{mg}$ b.i.d was superior to placebo for shortterm prophylaxis of MAM in $3 \mathrm{RCTs}$, and naratriptan halved the MAM in one RCT [19], whereas in 2 RCTs $36 \%$ were without MAM versus $27 \%$ for placebo $[12,13]$; these results suggest a modest effect of short-term prophylaxis with naratriptan in MAM.

Naratriptan was evaluated in 3 RCT versus the NSAID, naproxen sodium [8-10] (see Table 1). In two RCTs, naratriptan was not superior to naproxen sodium $375 \mathrm{mg}$ for migraine-related quality of life [8, 9]. In one RCT, more 
Table 1 Overview of 17 randomised, controlled trials with oral naratriptan for migraine treatment found in the GSK Trial Register (http://www. gsk-clinicalstudyregister.com/)

\begin{tabular}{|c|c|c|c|c|c|}
\hline Drugs used [reference] (protocol code in GSK register) & $\begin{array}{l}\text { Number of } \\
\text { centers }\end{array}$ & $\begin{array}{l}\text { Total number } \\
\text { of patients } \\
\text { (study design) }\end{array}$ & $\begin{array}{l}\text { Full } \\
\text { publication }\end{array}$ & Abstract(s) & Results \\
\hline $\begin{array}{l}\text { Na } 2.5 \mathrm{mg} \text { vs. naproxen sodium (NS) } 275 \mathrm{mg} \text { [8] } \\
\text { [S2WA4003] }\end{array}$ & 19 & $168(\mathrm{P})$ & - & - & $\begin{array}{l}\text { Na and NS had similar effect on } \\
\text { MRQL }\end{array}$ \\
\hline Na $2.5 \mathrm{mg}$ vs. NS $275 \mathrm{mg}$ [9] [S2WA4004] & 20 & $171(\mathrm{P})$ & - & - & $\begin{array}{l}\text { Na and NS had similar effect on } \\
\text { MRQL }\end{array}$ \\
\hline $\mathrm{Na} 2.5 \mathrm{mg}$ vs. NS $500 \mathrm{mg}[10][\mathrm{S} 2 \mathrm{~W} 40010]^{\mathrm{a}}$ & 70 & $456(\mathrm{C})$ & - & - & $\begin{array}{l}\text { Preference: } \mathrm{Na}(34 \%)>\mathrm{NS} \\
\quad(26 \%)^{\mathrm{c}}\end{array}$ \\
\hline Na 2.5 mg vs. PL in mild MAM [11] [S2W40031] & 152 & $229(\mathrm{P})$ & + & - & $\begin{array}{l}\mathrm{Na}(58 \% \text { headache relief })>\mathrm{PL} \\
(30 \% \text { headache relief })\end{array}$ \\
\hline Na 1 mg b.i.d. vs. placebo for MAM [12] [S2W40012] & 51 & $187(\mathrm{P})$ & - & + & $\begin{array}{l}\text { Without MAM: Na } 38 \%>\text { PL } \\
29 \%\end{array}$ \\
\hline Na $1 \mathrm{mg}$ b.i.d. vs. PL [13] [S2W40024] & 61 & $236(\mathrm{P})$ & - & + & $\begin{array}{l}\text { Without MAM: Na } 34 \%>\text { PL } \\
24 \%\end{array}$ \\
\hline $\mathrm{Na} 0.1,0.25,1.0,2.5 \mathrm{mg}$ vs. PL [14] [S2WA3001] & 54 & $613(\mathrm{P})$ & + & + & $\begin{array}{l}\text { Na } 1 \mathrm{mg}(50 \%) \text { and } 2.5 \mathrm{mg} \\
(60 \%)>\mathrm{PL}(34 \%) \text { for headache } \\
\text { relief at } 4 \mathrm{~h}\end{array}$ \\
\hline $\mathrm{Na} 0.25,1.0$, and $2.5 \mathrm{mg}$ vs. PL [15] [S2WA3003] & 50 & $602(\mathrm{C})$ & + & + & $\begin{array}{l}\mathrm{Na} 1.0 \mathrm{mg}(57 \%) \text { and } 2.5 \mathrm{mg} \\
(68 \%)>\mathrm{PL}(33 \%) \text { for headache } \\
\text { relief after } 4 \mathrm{~h}\end{array}$ \\
\hline $\begin{array}{l}\text { Na } 0.25,1.0 \text {, and } 2.5 \mathrm{mg} \text { vs. placebo in adolescent } \\
\text { migraine [16] [S2WA3012] }\end{array}$ & 44 & $300(\mathrm{P})$ & - & + & $\begin{array}{l}\mathrm{Na} 0.25 \mathrm{mg}(72 \%), 1.0 \mathrm{mg}(67 \%) \\
\text { and } 2.5 \mathrm{mg}(64 \%) \text { were similar to } \\
\mathrm{PL}(65 \%) \text { for headache relief } \\
\text { after } 4 \mathrm{~h}\end{array}$ \\
\hline $\begin{array}{l}\mathrm{Na} 2.5 \mathrm{mg} \text { vs. PL in pt not responding to sumatriptan } \\
\text { [17] [S2WA4002] }\end{array}$ & 57 & $206(382)(\mathrm{P})^{\mathrm{b}}$ & + & + & $\begin{array}{l}\mathrm{Na}(47 \%)>\mathrm{PL}(20 \%) \text { for } \\
\text { headache relief after } 4 \mathrm{~h}\end{array}$ \\
\hline $\begin{array}{l}\text { Na } 2.5 \text { mg b.i.d. vs. PL in transformed migraine [18] } \\
\text { [S2WA4005] }\end{array}$ & 11 & $170(\mathrm{P})$ & - & - & $\begin{array}{l}\text { Na (13\%) similar to PL (17\%) for } \\
\text { no headache on days } 13 \text { and } 14 .\end{array}$ \\
\hline $\begin{array}{l}\text { Na } 1 \mathrm{mg} \text { and } 2.5 \mathrm{mg} \text { b.i.d. vs. PL in MAM [19] } \\
\text { [S2WA4006] }\end{array}$ & 18 & $206(\mathrm{P})$ & + & + & $\begin{array}{l}\text { Median MAM over } 4 \\
\text { menstruation: } \mathrm{PL}=4, \\
1 \mathrm{mg}=2,2.5 \mathrm{mg}=3 . \mathrm{Na} \\
1.0 \mathrm{mg}<\mathrm{PL}(p=0.011)\end{array}$ \\
\hline $\begin{array}{l}\text { Na } 2.5 \mathrm{mg} \text { vs. sumatriptan } 100 \mathrm{mg} \text { in recurrence prone } \\
\text { patients [20] [S2WB3011] }\end{array}$ & 34 & $236(\mathrm{C})$ & + & + & $\begin{array}{l}24 \text { h overall efficacy: } \mathrm{Na}(40 \%) \\
\text { similar to sumatriptan }(35 \%)\end{array}$ \\
\hline $\begin{array}{l}\text { Na } 0.1 \mathrm{mg}, 0.25 \mathrm{mg}, 1.0 \mathrm{mg} \text {, and } 2.5 \mathrm{mg} \text { vs. } \\
\text { sumatriptan } 100 \mathrm{mg} \text { vs. placebo [21] [S2WB3002] }\end{array}$ & 113 & $1,141(942)(\mathrm{P})^{\mathrm{c}}$ & - & + & $\begin{array}{l}\text { Na } 1.0 \mathrm{mg}(52 \%) \text { and } 2.5 \mathrm{mg} \\
(66 \%)>\mathrm{PL}(27 \%) \text { for headache } \\
\text { relief at } 4 \mathrm{~h} \text {, sumatriptan }(76 \%) \\
\text { was superior to all Na doses }\end{array}$ \\
\hline $\begin{array}{l}\text { Na } 2.5 \mathrm{mg} \text { vs. sumatriptan } 50 \mathrm{mg} \text { in patients who } \\
\text { relapse from sumatriptan }(100 \mathrm{mg} \text { orally or } 6 \mathrm{mg} \\
\text { subcutaneously) [22] [S2WB4001] }\end{array}$ & 66 & $464(\mathrm{C})$ & - & - & $\begin{array}{l}\text { Satisfaction with overall } \\
\text { effectiveness: very satisfied or } \\
\text { satisfied: } \mathrm{Na}(52 \%) \text { similar to } \\
\text { sumatriptan }(48 \%)\end{array}$ \\
\hline Na $5 \mathrm{mg}$ and $10 \mathrm{mg}$ vs. placebo [23] [S2WB2003] & 10 & $90(\mathrm{P})$ & - & - & $\begin{array}{l}\text { Headache relief at } 4 \mathrm{~h}: \mathrm{Na} 5 \mathrm{mg} \\
(89 \%) \text { and } 10 \mathrm{mg}(72 \%)>\mathrm{PL} \\
(33 \%)\end{array}$ \\
\hline $\begin{array}{l}\mathrm{Na} 1,2.5,5,7.5 \text {, and } 10 \mathrm{mg} \text { vs. sumatriptan } 100 \mathrm{mg} \text { and } \\
\text { vs. PL }[24][\mathrm{S} 2 \mathrm{WB} 2004]\end{array}$ & 74 & $637(\mathrm{P})$ & + & + & $\begin{array}{l}\text { For headache relief at } 4 \mathrm{~h} \text { all doses } \\
\text { of } \mathrm{Na}(64 \%, 63 \%, 65 \%, 80 \% \text {, and } \\
80 \%) \text { were superior to PL (39\%) } \\
\mathrm{Na} 7.5 \mathrm{mg} \text { and } 10 \mathrm{mg} \text { were } \\
\text { similar to sumatriptan } 100 \mathrm{mg} \\
(80 \%) \text {, which was superior to } \mathrm{Na} \\
1,2.5 \text {, and } 5 \mathrm{mg}\end{array}$ \\
\hline
\end{tabular}

$C$ crossover, $P$ parallel group, $N a$ naratriptan, $N S$ naproxen sodium, $M R Q L$ migraine-related quality of life, $P L$ placebo, $M A M$ menstruation-associated migraine

${ }^{a}$ Patients dissatisfied with simple analgesics in the treatment of migraine attacks

${ }^{b}$ Number of patients treated with a single-blind dose of sumatriptan $50 \mathrm{mg}$

c Number of patients completing and treating 3 attacks

${ }^{\mathrm{d}}$ Complete headache relief after $4 \mathrm{~h}$ was $39 \%$ in both treatment groups 
Headache relief for sumatriptan $100 \mathrm{mg}$ and

$\% \quad$ naratriptan $2.5 \mathrm{mg}$ [S2bw3002]

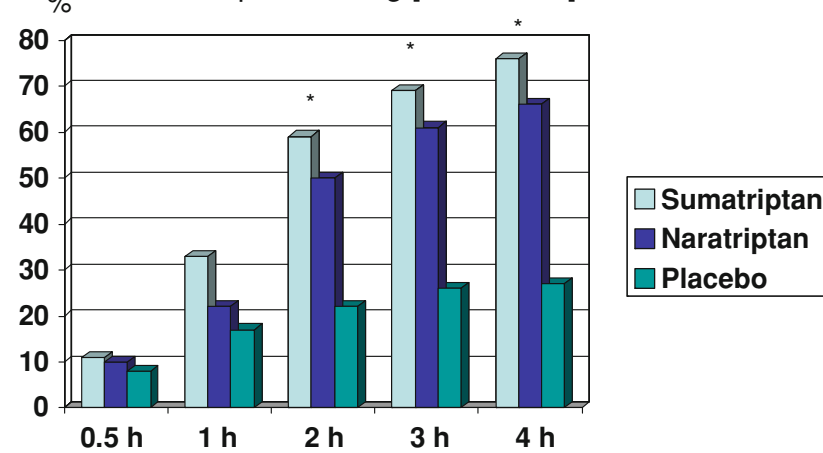

Fig. 1 The mean headache relief for sumatriptan $100 \mathrm{mg}$, placebo, and naratriptan $2.5 \mathrm{mg}$ up to $4 \mathrm{~h}$ in one not-fully published RCT [21]. $* p<0.05$ for difference between naratriptan versus sumatriptan

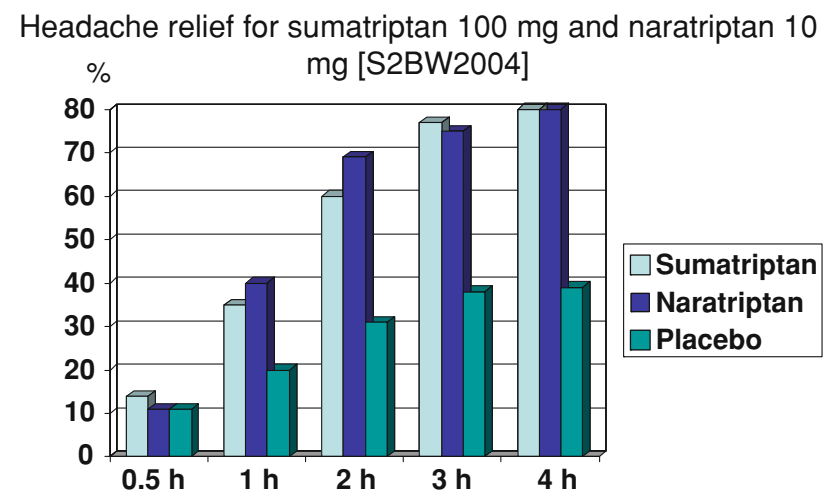

Fig. 2 The mean headache relief for sumatriptan $100 \mathrm{mg}$, placebo, and naratriptan $10 \mathrm{mg}$ up to $4 \mathrm{~h}$ in one RCT [23]

patients $(34 \%)$ preferred naratriptan than naproxen sodium $500 \mathrm{mg}(25 \%)$ [10]. It is unclear why naratriptan $2.5 \mathrm{mg}$ is similar to naproxen $375 \mathrm{mg}$ but better than the higher 500 -mg dose of naproxen sodium. It may be due to the design of the studies.

In conclusion, the investigators are obligated to the migraine patients participating in the trials, who often endured placebo administration for $4 \mathrm{~h}$, to ensure that the results of well-conducted, randomised trials are published in peer-reviewed journals. This can be difficult when there are multicenter trials with many investigators, and I suggest that investigators choose a publication committee among themselves, e.g. one from each country or each region.

In this review, all double-blind RCTs with oral naratriptan in the treatment of migraine are presented [8-24]. This does not change the overall picture of an effective and well-tolerated triptan [3]. Whereas naratriptan is superior to placebo, the $2.5-\mathrm{mg}$ dose chosen is less effective than sumatriptan $100 \mathrm{mg}$ ( 2 and $4 \mathrm{~h}$ ) (see Table 1), and rizatriptan $10 \mathrm{mg}(2 \mathrm{~h})$ [28]. The inferiority of naratriptan versus most other triptans at $2 \mathrm{~h}$ has been shown in meta- analyses $[1,2,4]$, and this has been ascribed to a slow action of naratriptan [5]. The apparent slow onset of naratriptan $2.5 \mathrm{mg}$ is, however, a matter of dose (see above).

When naratriptan $2.5 \mathrm{mg}$ became an OTC drug, the question of its efficacy compared with other OTC drugs and NSAIDs became relevant. Naratriptan was not compared with paracetamol or aspirin, which in an effervescent form (52\% headache relief) was found to have similar efficacy as sumatriptan $50 \mathrm{mg}$ (46\% headache relief) in a meta-analysis [28]. There are 2 RCTs comparing naratriptan $2.5 \mathrm{mg}$ with naproxen sodium $275 \mathrm{mg}$ (Table 1). Unfortunately, no placebo-control was used in the RCTs, but no differences between the active drugs were observed. Patients' preference for naratriptan (34\%) was marginally superior to naproxen sodium (26\%) (Table 1) in patients dissatisfied with simple analgesics [10]. What is missing is a comparative RCT of naratriptan $2.5 \mathrm{mg}$ (50\% headache relief Table 1), and lysine acetylsalicylate and metoclopramide, which showed headache relief of $56 \%$ in 2 RCTs [29, 30]. Until such comparative RCTs become available, one cannot, based on the available evidence, recommend what migraine patients should try next when they are dissatisfied with simple analgesics. Naratriptan is a reasonable OTC choice as second or third choice on the step care ladder.

\section{Conflict of interest None.}

Open Access This article is distributed under the terms of the Creative Commons Attribution License which permits any use, distribution and reproduction in any medium, provided the original author(s) and source are credited.

\section{References}

1. Tfelt-Hansen P, De Vries P, Saxena PR (2000) Triptans in migraine. A comparative review of pharmacology, pharmacokinetics and efficacy. Drugs 60:1259-1287

2. Ferrari MD, Roon KI, Lipton RB, Goadsby PJ (2001) Oral triptans (serotonin 5-HT (1B/1D) agonists in the acute migraine treatment: a metaanalysis of 53 triptans. Lancet 358:1668-1675

3. Aschcroft DM, Millson D (2004) Naaratriptan for the treatment of acute migraine: meta-analysis of randomised controlled trials. Pharmacoepidemiology 13:73-82

4. Saxena PR, Tfelt-Hansen P (2006) Triptans, 5HT1B/1D agonists in the acute treatment of migraine. In: Olesen J, Goadsby PJ, Ramadan NM, Tfelt-Hansen P, Welch KMA (eds) The headaches, 3rd edn. Lippincott Williams and Wilkins, Philadelphia, pp 469-50

5. Salonen R (2001) Naratriptan: the gentle triptan. In: Humphrey PP, Ferrari MD, Olesen J (eds) The triptans: novel drugs for migraine. Oxford University Press, New York, pp 228-235

6. Ethics Subcommittee of the International Headache Society (2008) Ethical issues arising from commercial sponsorship and from relationship with the pharmaceutical industry-report and 
recommendations of the Ethics Committee of the International Headache Society. Cephalalgia 28(Suppl 3):1-25

7. Tfelt-Hansen P (2009) Unpublished sumatriptan clinical trials. Lancet 374:1501-1502

8. A randomized, double-blind, double-dummy, active-placebo controlled, parallel group evaluation of oral naratriptan $(2.5 \mathrm{mg})$ compared o oral naproxen sodium $(275 \mathrm{mg})$ on migraine-related quality of life. Study no. S2WA4003. http://www.gsk-clinical studyregister.com. Accessed 28 January 2011

9. A randomized, double-blind, double-dummy, active-placebo controlled, parallel group evaluation of oral naratriptan $(2.5 \mathrm{mg})$ compared o oral naproxen sodium $(275 \mathrm{mg})$ on migraine-related quality of life. Study no. S2WA4004. http://www.gsk-clinical studyregister.com/). Assessed 28 January 2011

10. A randomised, double-blind, cross-over study to compare the patient preference of oral naratriptan $\left(\mathrm{Naramig}^{\mathrm{TM}}\right) 2.5 \mathrm{mg}$ with naproxen $500 \mathrm{mg}$ in patients dissatisfied with simple analgesics in the treatment of acute migraine. Study no.: S2W40010. http://www.gsk-clinicalstudyregister.com/. Assessed 28 January 2011

11. Massiou H, Jamin C, Hinzelin G, Bidaut-Mazel C, and The French Naramig Collaborative Study Group (2005) Efficacy of oral naratriptan in the treatment of menstrually related migraine. Eur J Neurol 12:1-8

12. Mannix LK, Savani N, Landy S, Valade D, Schackelford S, Ames $M$ et al (2007) Efficacy and tolerability of naratriptan for shortterm prevention of menstrually related migraine: data from two randomized, double-blind, placebo-controlled studies. Headache 47:1037-1049

13. A randomised, double-blind, placebo-controlled, parallel group evaluation of oral naratriptan $1 \mathrm{mg}$ twice daily as prophylactic treatment for menstrually associated migraine. Study no. S2W40024. http://www.gsk-clinicalstudyregister.com/. Assessed 28 January 2011

14. Klassen A, Elkind A, Asgharnejad M, Webster C, Laurenza A (1997) Naratriptan is effective and well tolerated in the acute treatment of migraine: results of a double-blind, placebo-controlled, parallel-group study. Headache 37:640-645

15. Mathew N, Asgharnejad M, Peykamian M, Laurenza A (1997) Naratriptan is an effective and well tolerated in the acute treatment of migraine. Results of a double-blind, placebo-controlled, crossover study. Neurology 49:1485-1490

16. Rothner A (1997) Efficacy and safety of naratriptan tablets in adolescent migraine. J Neurol Sci 150(Suppl):S106

17. Stark S, Spierings EL, McNeal S, Putman GP, Bolden-Watson CP, O'Quinn S et al (2000) Naratriptan efficacy in migraineurs who respond poorly to oral sumatriptan. Headache 40:513-520

18. A randomized, double-blind, placebo-controlled, parallel group evaluation of oral naratriptan $(2.5 \mathrm{mg})$ administered twice daily in the treatment of transformed migraine. Study no.: S2WA4005. www.gsk-clinicalstudyregister.com/. Assessed 28 January 2011

19. Newman L, Mammix LK, Landy S, Silberstein S, Lipton RB, Putman DG et al (2001) Naratriptan as short-term prophylaxis of menstrually associated migraine: a randomized, double-blind, placebo-controlled study. Headache 41:248-256

20. Göbel H, Winter P, Boswell D, Crisp A, Becker W, Hauge T, Milhout B et al (2000) Comparison of naratriptan and sumatriptan in recurrence-prone migraine patients. Naratriptan International Recurrence Study Group. Clin Ther 22:981-989

21. Bates D (1998) Efficacy and tolerability of naratriptan tablets $(0.1-2.5 \mathrm{mg})$ in the acute treatment of migraine. Eur J Neurol 5(Suppl 3):S48-S49

22. A randomised, double-blind, cross-over study to investigate patient overall satisfaction with efficacy and tolerability of oral naratriptan $2.5 \mathrm{mg}$ vs. oral sumatriptan $50 \mathrm{mg}$ for the treatment of patients who lapse from $100 \mathrm{mg}$ oral or $6 \mathrm{mg}$ subcutaneous sumatriptan. Study no. S2WB4001. http://www.gsk-clinicalstudy register.com/. Assessed 28 January 2011

23. A double-blind, placebo-controlled, randomised, parallel group study to evaluate the safety and efficacy of oral naratriptan $(5 \mathrm{mg}$ and $10 \mathrm{mg}$ ) following dosing during a migraine attack. Study no.: S2WB 2003. http://www.gsk-clinicalstudyregister.com/. Assessed 28 January 2011

24. Havanka H, Dahlöf C, Pop PH, Diener HC, Winter P, Whitehouse $\mathrm{H}$ et al (2000) Efficacy of naratriptan tablets in the acute treatment of migraine: a dose-ranging study. Naratriptan S2WB2004 Study Group. Clin Ther 22:970-980

25. Smyth RM, Kirkham JJ, Jacoby A, Altman DG, Gamble C, Williamson PR. Frequency and reasons for outcome reporting bias in clinical trials: interviews with trialists. BMJ (in press)

26. Eyding D, Lelgemann M, Grouven U, Härter M, Kromp M, Kaiser $\mathrm{T}$ et al (2010) Reboxetine for acute treatment of major depression: systematic review, meta-analysis of published, unpublished placebo, serotonin reuptake inhibitor controlled trial. BMJ 341:c4737

27. Tfelt-Hansen P (2000) A comment on time-to-event analysis or headache relief. Cephalalgia 20:255-256

28. Bomhof M, Paz J, Legg N, Allen C, Vandomael K, Patel K (1999) Comparison of rizatriptan $10 \mathrm{mg}$ vs. naratriptan $2.5 \mathrm{mg}$ in migraine. Eur Neurol 42:173-179

29. Chabriat H, Joire JE, Danchot J, Grippon P, Bousser MG (1994) Combined oral lysine acetylsalicylate and metoclopramide in the acute treatment of migraine: a multicentre double-blind placebocontrolled study. Cephalalgia 14:297-300

30. Tfelt-Hansen P, Henry P, Mulder K, Scheldewaert RG, Schoenen J, Chazot G (1995) The effectiveness of combined oral lysine acetylsalicylate and metoclopramide compared with oral sumatriptan for migraine. Lancet 346:923-926 